\title{
Effects of an exercise program on blood pressure in patients with treated hypertension and chronic Chagas' heart disease
}

\author{
Claudia Rosa de Oliveira ${ }^{[1]}$, Andréa Silvestre de Sousa ${ }^{[1],[2]}$, Bráulio Santos ${ }^{1}$, Paloma Hargreaves Fialho ${ }^{[1]}$, \\ Carla Cristiane Soares dos Santos ${ }^{[1]}$, Juliana Rega de Oliveira ${ }^{[1]}$ and Marcus Vinícius Souza ${ }^{[1]}$
}

[1]. Serviço de Fisioterapia, Instituto Nacional de Cardiologia, Rio de Janeiro, RJ. [2]. Instituto de Pesquisa Clínica Evandro Chagas, Fundação Oswaldo Cruz, Rio de Janeiro, RJ.

\section{ABSTRACT}

Introduction: Previous studies describe an imbalance of the autonomic nervous system in Chagas' disease causing increased sympathetic activity, which could influence the genesis of hypertension. However, patients undergoing regular physical exercise could counteract this condition, considering that exercise causes physiological responses through autonomic and hemodynamic changes that positively affect the cardiovascular system. This study aimed to evaluate the effects of an exercise program on blood pressure in hypertensive patients with chronic Chagas' heart disease. Methods: We recruited 17 patients to a $24-$ week regular exercise program and used ambulatory blood pressure monitoring before and after training. We determined the differences in the systolic blood pressure (SBP), diastolic blood pressure (DBP), and mean blood pressure (MBP) from the beginning to the end of the study. Results: The blood pressures were evaluated in general and during periods of wakefulness and sleep, respectively: SBP $(p=0.34 ; 0.23 ; 0.85), \operatorname{DBP}(p=0.46 ; 0.44 ; 0.94)$ and MBP $(p=0.41 ; 0.30$; 0.97). Conclusions: There was no statistically significant change in blood pressure after the 24-week exercise program; however, we concluded that physical training is safe for patients with chronic Chagas' disease, with no incidence of increase in blood pressure.

Keywords: Chagas' heart disease. Hypertension. Exercises. Ambulatory blood pressure monitoring.

\section{INTRODUCTION}

Chagas' disease is an important public health issue in Latin America, occurring all over South America, from Chile and Argentina to the south of the United States; in Brazil it is the fourth highest cause of death by parasitic infection ${ }^{1}$. The illness results from infection with the parasitic flagellate Trypanosoma cruzi ${ }^{2}$, and transmission occurs mainly through insect vectors of the Triatominae family, in whose excrement the infectious forms of the parasite are found ${ }^{3}$.

It is estimated that there are still 8-10 million infected people in Latin America ${ }^{4}$ and that 60 million people are exposed to the danger of contracting the illness ${ }^{5}$. Migratory patterns in the 1970s saw large contingents of infected individuals moving to the big cities; the result being that today, Chagas' disease is known as a truly endemic urban disease $\mathrm{s}^{5}$.

Arterial hypertension is considered one of the main risk factors of cardiovascular morbidity and mortality, affecting over $30 \%$ of the adult population aged over 18 years, and reaching levels greater than $50 \%$ among seniors aged between 60 and 69 years and $75 \%$ amongst those over 70 years old ${ }^{6}$. The social cost is high as it is responsible for around $40 \%$ of cases of early retirement ${ }^{7}$. It is believed that its prevalence in patients with Chagas' disease is similar to that of the general population ${ }^{8,9}$, despite the neuronal damage associated with the illness, which is responsible for an imbalance in the autonomic nervous system, causing greater sympathetic activity that could influence the genesis of arterial hypertension ${ }^{8,9}$. With this theory in mind, research

Address to: Dra. Claudia Rosa de Oliveira. Serviço de Fisioterapia/INC. Rua das Laranjeiras 374/80 andar, 22240-006 Rio de Janeiro, RJ, Brasil.

Phone: 5521 7891-9752

e-mail: claudiarosaft@bol.com.br

Received in 17/02/2011

Accepted in 23/03/2012 into the link between arterial hypertension and chronic Chagas' heart disease is considered relevant.

Physical exercise provokes a series of physiological responses resulting from autonomic and hemodynamic modifications that influence the cardiovascular system ${ }^{6}$. The benefits of regular physical activity to the blood pressure of cardiac patients are well known ${ }^{10,11}$; however, there is no specific scientific evidence in patients with Chagas' disease. The objective of this study was to evaluate the potential effects of an exercise program on the blood pressure of patients with chronic Chagas heart disease.

\section{METHODS}

Seventeen patients with treated hypertension and chronic Chagas' heart disease were evaluated in a prospective intervention study. The patients participated in an exercise program at the Exercise Program Service of the National Institute of Cardiology (INC). The main outcome of this study was the difference between the average blood pressure measured by ambulatory blood pressure monitoring carried out before and 24 weeks after intervention.

The exercise program was carried out in 1-hour sessions 3 times every week, as follows: I) $30 \mathrm{~min}$ of aerobic exercise on Inbrasport $2000^{\text {tw }}$ Treadmills Brazil, II) $20 \mathrm{~min}$ of empirically programmed resistance exercises for the main muscle groups, with 2 series of 10 repetitions for each of the main muscle groups, applying a load that provided the patient with a sensation of moderate effort (Table 1); and III) 10min of extension for all of the muscle groups exercised, with each position held for 20sec. The aerobic exercise on the treadmills were further divided into 3 phases: A) $5 \mathrm{~min}$ warm-up with progressive acceleration; B) $20 \mathrm{~min}$ of exertion aiming within the target cardiac frequency zone, associated to the perceived exertion according to the modified Borg scale ${ }^{12}$, and maintaining the intensity of the effort between moderate and moderate/intense; and (c) 5-min cool-down until the treadmill reached a complete stop. 
TABLE 1 - Resistance exercises.

\begin{tabular}{lcc}
\hline Exercises & Series & Repetitions \\
\hline Leg extension & 2 & 10 \\
Reclined rowing on pulley & 2 & 10 \\
Bilateral plantar flexion on step & 2 & 20 \\
Lateral arm raise & 2 & 10 \\
Standing unilateral knee flexion & 2 & 10 \\
Triceps twist with rope & 2 & 10 \\
Straight abdominal & 2 & 20 \\
Oblique abdominal with crossed leg & 2 & 20 \\
Standing unilateral hip abduction & 2 & 10 \\
\hline
\end{tabular}

For safety reasons, blood pressure was measured before, $20 \mathrm{~min}$ after beginning exercise, and at the end of each exercise session.

The study included men and women aged between 18 and 75 years diagnosed with chronic Chagas' heart disease and systemic arterial hypertension (SAH) who were in outpatient treatment. Antihypertensive medication was maintained throughout the study at the discretion of the assisting doctor without intervention from the researchers. The main drugs used in antihypertensive therapy were angiotensin-converting enzyme inhibitors/angiotensin receptor blockers, beta-blockers, thiazides, and calcium channel blockers. The inclusion of patients with basal blood pressure controlled by medication, with drug dosage evaluated before and after the exercise. All of the patients presented low or moderate risk for an exercise program and did not take regular physical exercise. The diagnosis of chronic Chagas' heart disease was based on the Brazilian consensus on Chagas' disease ${ }^{13}$ through confirmation of electrocardiographic and echocardiographic alterations characteristic in individuals seropositive for Chagas' disease using two different techniques: enzyme-linked immunosorbent assay, hemagglutination, or indirect immunofluorescence.

To evaluate the severity of chronic Chaga's heart disease the following parameters were used: general clinical examination, cardiopulmonary stress test, conventional electrocardiogram, and Doppler echocardiogram. The examinations were carried out before and after the exercise program with a maximum lag of 1 month for each period.

Patients with associated angina pectoris as well as those whose stress tests were suspended due to clinical or electrocardiographic evidence of myocardial ischemia, clinically evident thyroidal dysfunction, orthopedic involvement limiting the use of a treadmill, cancer, hepatopathy, serious alcoholism, or chronic nephropathies were excluded.

Before analysis, the distribution of the arterial pressure variables was tested by the Shapiro Wilk normality test, and it proved to be normally distributed. Therefore, the variables were expressed as mean \pm SD and were compared before and after the exercise program employing the paired Student $t$-test. The differences were considered statistically significant when a 2-tailed $p$-value equaled or was less than $5 \%$ ( $p \leq 0.05$ ). We employed the $R$ software packages ( $R$ Foundation for Statistical Computing, version 2.11, Vienna, Austria, 2011) for processing, analysis, and graphic design of the data.

\section{Ethical considerations}

This study was approved by the ethics committee and used the recommendations of the World Health Organization, the Helsinki Statement of Rights, and the National Committee for Ethics in Research (CONEP) resolution 196/96. The entire study process was explained to the patients, and their authorization was recorded in their patient file by the examiner; the patients signed a willing consent form that had been explained to them.

\section{RESULTS}

The study recruited 32 patients, of which 12 were excluded due to difficulty in adhering to the exercise program; there were also isolated losses due to transitory ischemic attack, dorso- lumbalgia and desistance during the course of the study. In the end, 17 patients concluded the program.

This was the demographic profile of these 17 patients: the median age was 60.0 years, interquartile range 25-75: 55-62 (30-72years); mean \pm weight SD $67.96 \pm 12.3 \mathrm{Kg}(41-93.8 \mathrm{Kg})$; mean height \pm SD 1.61 $\pm 0.098 \mathrm{~m}(1.44-1.82 \mathrm{~m})$; and mean body mass index \pm SD $26.22 \pm 4.3 \mathrm{Kg} \cdot \mathrm{m}^{-2}\left(15.6-37.6 \mathrm{Kg} \cdot \mathrm{m}^{-2}\right)$.

Blood pressure values before and after the 24-week regular exercise program were described in Table 2. Overall variation in blood pressure before and after the exercise program, during wakefulness and sleep were described in Figures 1, 2, and 3, respectively.

TABLE 2 - Blood pressure values before and after 24-week regular exercise program.

\begin{tabular}{|c|c|c|c|c|c|c|c|}
\hline & & \multicolumn{2}{|c|}{$\begin{array}{c}\text { Average } \pm \\
\text { standard deviation }\end{array}$} & \multicolumn{2}{|c|}{ Variation } & \multirow{2}{*}{$\begin{array}{c}\text { Difference in } \\
\text { values } \\
\text { (post-pre) }\end{array}$} & \multirow[b]{2}{*}{$p$} \\
\hline & & pre & post & pre & post & & \\
\hline \multirow[t]{3}{*}{ SBP } & GS & $123.4 \pm 16.4$ & $118.9 \pm 10$ & 98-159 & $97-140$ & "41 to 13 & 0.34 \\
\hline & W & $126.2 \pm 15.7$ & $120.8 \pm 9.5$ & $104-161$ & $100-133$ & "38 to 15 & 0.23 \\
\hline & $S$ & $114.7 \pm 18.2$ & $113.6 \pm 15.1$ & 84-152 & $87-155$ & “52 to 23 & 0.85 \\
\hline \multirow[t]{3}{*}{ DBP } & GS & $74.41 \pm 11.1$ & $71.88 \pm 8.8$ & $54-94$ & 57-91 & $\mathrm{H} 23$ to 10 & 0.46 \\
\hline & W & $77.18 \pm 10.8$ & $74.59 \pm 8.7$ & $56-97$ & $57-90$ & $\mathrm{H} 21$ to 9 & 0.44 \\
\hline & $S$ & $65.65 \pm 12.4$ & $65.94 \pm 11.7$ & $48-86$ & $47-94$ & $\mathrm{H} 30$ to 14 & 0.94 \\
\hline \multirow[t]{3}{*}{ MBP } & GS & $91.7 \pm 13.1$ & $88.59 \pm 8.5$ & $75-120$ & $73-107$ & $\mathrm{H} 32$ to 10 & 0.41 \\
\hline & W & $93.53 \pm 12.5$ & $90.76 \pm 7.9$ & $78-121$ & $76-104$ & "28 to 10 & 0.30 \\
\hline & $S$ & $82.88 \pm 14.6$ & $82.76 \pm 12.2$ & $62-114$ & $60-103$ & $\mathrm{H} 41$ to 15 & 0.97 \\
\hline
\end{tabular}

SBP: systolic blood pressure; DBP: diastolic blood pressure; MBP: mean blood pressure; GS: general summary; W: wakefulness; S: sleep; pre: start of study; post: end of study: 


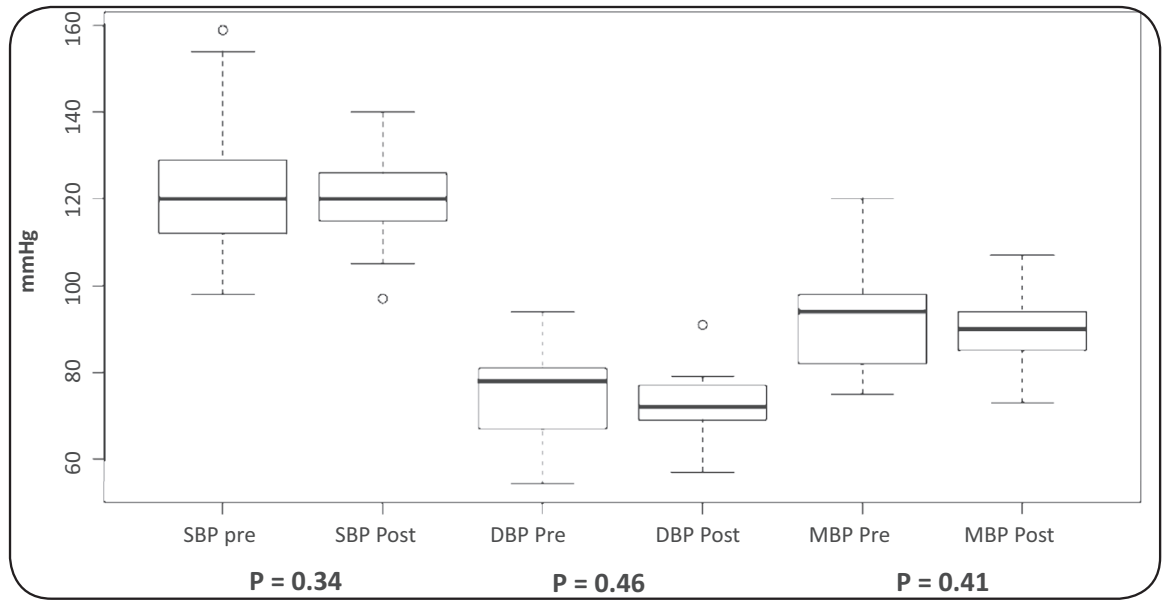

FIGURE 1 - Overall variation in blood pressure before and after the exercise program- SBP-pre: systolic blood pressure before exercise program; SBP-post: systolic blood pressure after exercise program; DBP-pre: diastolic blood pressure before exercise program; DBP-post: diastolic blood pressure after exercise program; MBP-pre: mean blood pressure before exercise program; and MBP-post: mean blood pressure after exercise program.

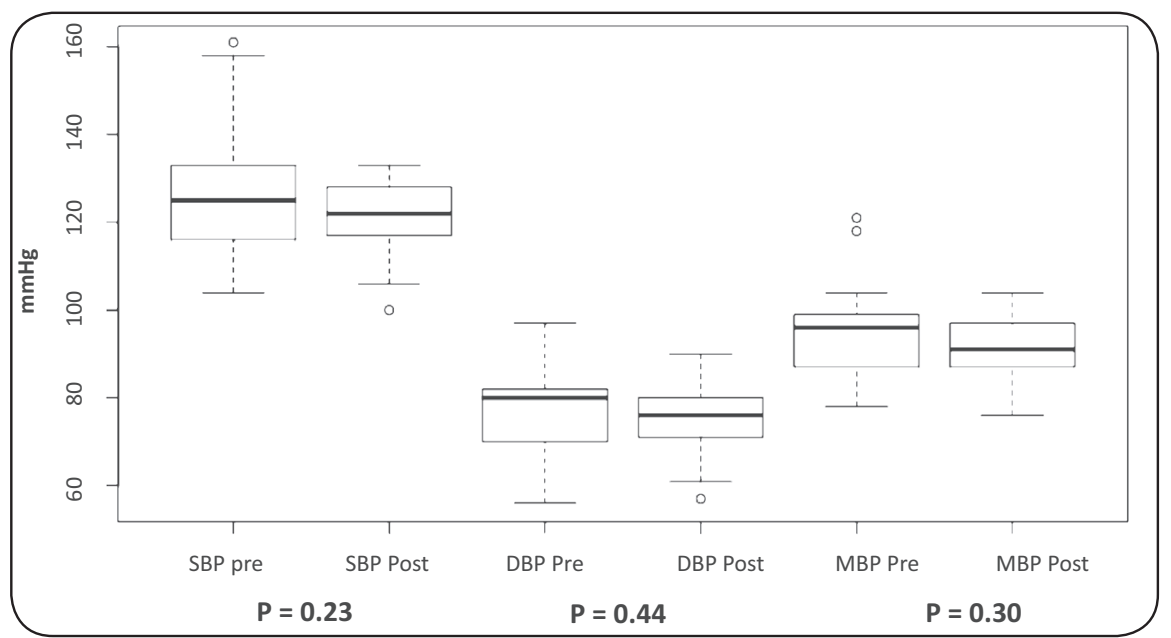

FIGURE 2 - Blood pressure variation during wakefulness before and after the exercise program._SBP-pre: systolic blood pressure before exercise program; SBP-post: systolic blood pressure after exercise program; PAD-pre: diastolic blood pressure before exercise program; DBP-post: diastolic blood pressure after exercise program; MBP-pre: mean blood pressure before exercise program; and MBP-post: mean blood pressure after exercise program:

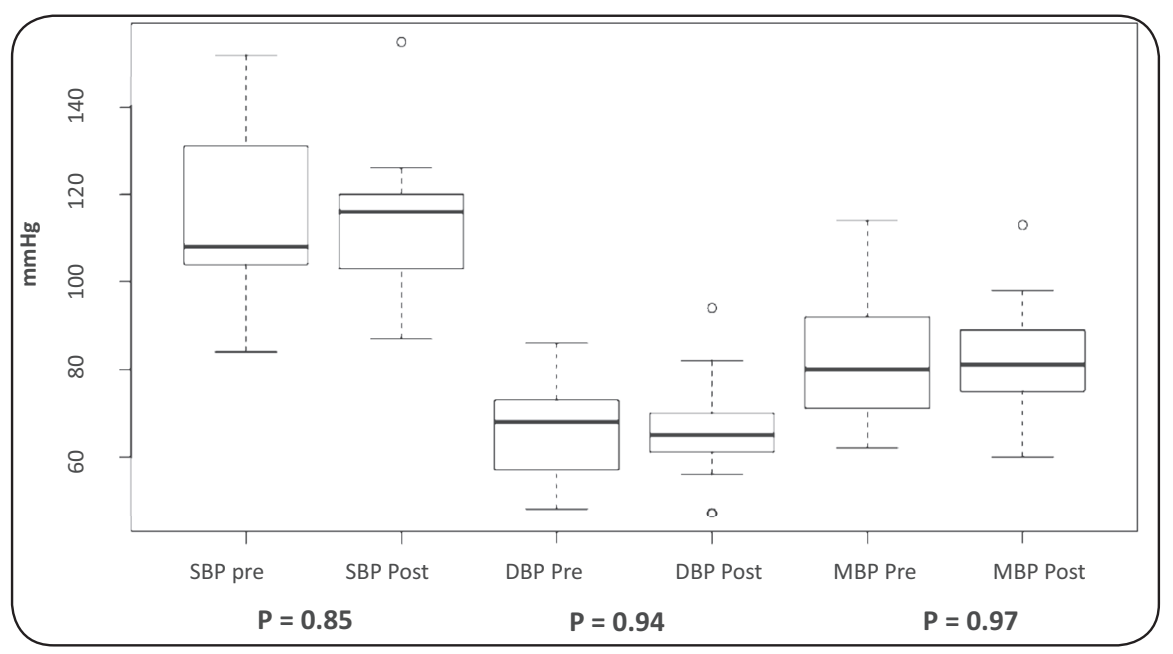

FIGURE 3 - Blood pressure variation during sleep before and after the exercise program. SBP-pre: systolic blood pressure before exercise program; SBP-post: systolic blood pressure after exercise program; PAD-pre: diastolic blood pressure before exercise program; DBP-post: diastolic blood pressure after exercise program; MBP-pre: mean blood pressure before exercise program; and MBP-post: mean blood pressure after exercise program

\section{DISCUSSION}

The damage to the autonomic nervous system stands out amongst the alterations described in chronic Chagas' heart disease, with a predominance of dysfunction of the parasympathetic system ${ }^{14,15}$, enabling sympathetic system activity, which could contribute to the development of arterial hypertension ${ }^{8,9}$. On the other hand, the action of physical exercise attenuating sympathetic activity ${ }^{15,16}$ has been described, which make it necessary a study on the effect of physical exercise on the variation of blood pressure in this group of people.

The literature contains few facts regarding concurrence between systemic arterial hypertension and Chagas' disease, and there is controversy over the frequency and the repercussion for patients when these 2 illnesses are associated ${ }^{8,17}$. Some studies have shown elevated blood pressure levels in the population with Chagas' disease ${ }^{18}$, while other authors have shown that Chagas' disease patients seem to have the same propensity as the general population to develop arterial hypertension ${ }^{8,9,19,20}$; still others, mainly in Argentina, have reported a decrease in blood pressure compared to the general population ${ }^{21-23}$.

lanni et al observed a group of 160 patients with the indeterminate form of Chagas' disease for up to 177 months, and reported that SAH was the most frequent cardiovascular illness ${ }^{20}$. Guariento et al aimed to define the association between Chagas disease and primary arterial hypertension and concluded that, when associated, cardiac compromise was more frequent and serious, this association being more prevalent in the elderly ${ }^{17}$. Gurgel et al retrospectively studied 225 hypertensive patients with Chagas' disease to verify the frequency of SAH in that group, and found similarity with the population in general ${ }^{9}$. In a clinical and anatomopathological study, Gurgel and Almeida also evaluated the frequency of SAH in patients with Chagas' disease, obtaining similar results to the previous study and concluding that the association of the 2 illnesses did not alter the natural history of either ${ }^{8}$. Bertanha et al evaluated 125 patients with Chagas' disease, of which 69 were hypertensive, and verified that the latter were older, predominantly women, and had more elevated levels of glycemia, low-density lipoprotein cholesterol and total cholesterol, diabetes, greater cardiac damage, and left ventricular overload. They concluded that hypertensive Chagas' disease patients 
presented similar clinical-laboratory characteristics to the hypertensive population in general. In our study, we did not evaluate the frequency of arterial hypertension, limiting the discussion to studies that are relevant to this matter.

The positive effect of physical exercise on the cardiovascular system has been reported in various studies ${ }^{24,25}$; however, no studies confirm the response of hypertensive patients with Chagas' disease to an exercise program.

The hypotensive effect of physical activity on hypertensive patients has been reported in various studies ${ }^{26,27}$, but in spite of the studies demonstrating a decrease in blood pressure, the subjects in question did not have a Chagas' disease diagnosis.

In our study, we evaluated the effect of a 24-week, supervised physical activity program on treated hypertensive patients with chronic Chagas' heart disease. We determined no significant statistical difference in the blood pressure variation of the exercise program participants. The simple fact of not being reduced (as expected in healthy individuals) can mean an inadequate response of blood pressure in patients with chronic Chagas' heart disease. However, as there was no increase in blood pressure during the physical training, an exercise program can be a safe procedure for patients with treated hypertension. All of the patients in the study were hypertensives previously taking anti-hypertensive medication, and there was no dose adjustment during the physical training, with the exception of 1 patient whose medication was increased according to the patient, for reasons pertaining to emotions during a certain period of the program.

This result was similar to a study that evaluated physical training in patients with chronic Chagas' heart disease for 12 weeks, showing that exercise was well tolerated and safe ${ }^{28}$.

The dysautonomia in Chagas' disease could justify the result obtained in this study. Physical exercise is expected to diminish the sympathetic tonus and to increase the parasympathetic tonus of the autonomic nervous system, causing a reduction of systolic blood pressure (SBP) and diastolic blood pressure (DBP), respectively. However, when we studied the wakefulness period where sympathetic tonus is predominant, its reduction should have caused a significant reduction of SBP, but the reduction was less than that generally seen in other studies. We may attribute this result to a certain degree of dysautonomia with sympathetic hyperactivity. During sleep, there is normally a reduction in sympathetic tonus with a decrease of SBP and an increase in parasympathetic tonus with a decrease of DBP. However, the sleep-period study revealed an insignificant increase of SBP and a 6 -fold increase in DBP, which suggests parasympathetic dysautonomia.

There was no statistically significant difference between the group of excluded patients and research participants both in terms of age $=(p 0.93)$, as sex $=(p 0.08)$, weight $=(p 0.45)$ and baseline blood pressure $(S B P, p=0.50, D B P, p=0.15)$. Note only a trend toward greater female participation in the research protocol, a fact already shown in other studies, probably associated with greater responsiveness and adherence to treatment among women.

The limitations of the study include the relatively small number of hypertensive patients with Chagas' disease enlisted and the outpatients' non-adherence, which inhibited the study of socioeconomic development. The inclusion of patients undergoing antihypertensive treatments could explain the unchanged blood pressure in response to exercise, preventing direct evaluation of the effect of exercise on hypertension. Another limitation of this study was the non-inclusion of a control group of healthy subjects.

We concluded that there was no statistically significant change in blood pressure in patients who participated in the exercise program, showing that physical training is safe in treated hypertensive patients with chronic Chagas' disease, with no incidence of increase in blood pressure.

\section{ACKNOWLEDGMENTS}

We are grateful to Bernardo Rangel Tura for his participation fundamental to the existence of this work, the Marina Pereira Coelho need for collaboration and tireless, the Ademir Batista da Cunha by the participation of great importance to the study. We are grateful to members of staff in the sector cardiac rehabilitation (INC) for his competence, initiative and attention to members of the medical staff of ambulatory Chagas disease (Fiocruz) for his immeasurable contribution in the selection of patients and members of staff in sector hypertension (INC) for their collaboration and solicitude. We acknowledge the financial support from FAPERJ (Foundation for Research Support of the State of Rio de Janeiro) about the patients bus tickets.

\section{CONFLICT OF INTEREST}

The authors declare that there is no conflict of interest.

\section{ABSTRACT IN PORTUGUESE}

\section{Efeitos de um programa de exercícios na pressão arterial de pacientes com hipertensão controlada e cardiopatia chagásica crônica}

Introdução: Estudos prévios descrevem um desequilíbrio do sistema nervoso autônomo na doença de Chagas causando maior atividade simpática, o que poderia influenciar na gênese da hipertensão arterial. No entanto, pacientes submetidos a exercícios físicos regulares poderiam contrapor esta condição, visto que o exercício provoca respostas fisiológicas através de adaptações autonômicas e hemodinâmicas que influenciam positivamente o sistema cardiovascular. 0 presente estudo se propõe a avaliar os efeitos da reabilitação cardíaca sobre a pressão arterial em pacientes hipertensos com cardiopatia chagásica crônica. Métodos: Foram recrutados 17 pacientes submetidos a um programa regular de exercícios durante 24 semanas, sendo utilizado monitorização ambulatorial da pressão arterial (MAPA) antes e após o treinamento. Foi descrita a diferença da pressão arterial sistólica (PAS), pressão arterial diastólica (PAD) e pressão arterial média (PAM) do início ao fim estudo. Resultados: As pressões foram avaliadas de forma geral e nos períodos de vigília e sono, respectivamente: PAS ( $p=0,34 ; 0,23 ; 0,85)$, PAD ( $p=0,46 ; 0,44 ; 0,94)$ e PAM ( $p=0,41 ; 0,30 ; 0,97)$. Conclusões: Não houve diferença estatisticamente significativa na variação da pressão arterial após o período de reabilitação cardíaca de 24 semanas, no entanto, evidenciamos que o treinamento físico é seguro em pacientes com cardiopatia chagásica crônica, não ocorrendo aumento da pressão arterial.

Palavras-chaves: Cardiopatia chagásica. Hipertensão. Exercícios. Monitorização ambulatorial da pressão arterial.

\section{REFERENCES}

1. Escola Nacional de Saúde Pública. Epidemiology: current situation [Internet]. Fundação Oswaldo Cruz; 2010 [Cited 2010 Jan 27]. Available from: http://www. fiocruz.br/chagas. 
2. Kropf SP, Chagas HG, Justiniano CR. In: Bynum WF, Bynum H, editors. Dictionary of medical biography. Vol. 2. Connecticut/London: Greenwood Press; 2007; p. 320-325.

3. Ministério da Saúde. Guia de Vigilância Epidemiológica. 6ạ ed. Brasília, DF: Ministério da Saúde; 2005.

4. Marin-Neto JA, Rassi Jr A. Update on Chagas Heart Disease on the First Centennial of its Discovery. Rev Esp Cardiol 2009; 62:1211-1216.

5. Dias JC. Globalization, inequity and Chagas disease. Cad Saude Publica 2007; 23:13-22.

6. Sociedade Brasileira de Cardiologia. VI. Diretrizes de Hipertensão. Arq Bras Cardiol 2010; 95:1-51.

7. Sociedade Brasileira de Hipertensão, Sociedade Brasileira de Cardiologia e Sociedade Brasileira de Nefrologia. III Consenso Brasileiro de Hipertensão Arterial. Arq Bras Endocrinol Metab 1999; 43:257-286.

8. Gurgel CBFM, Almeida EA. Frequency of arterial hypertension in chronic Chagas patients and its repercussion on the heart: clinical and anatomopathological study. Arq Bras Cardiol 2007; 89:191-200.

9. Gurgel CBFM, Miguel Junior A, Mendes CR, Zerbini CO, Carcioni TM. Frequency of arterial hypertension in chronic Chagas disease. A retrospective clinical study. Arq Bras Cardiol 2003; 81:541-544.

10. I Consenso Nacional de Reabilitação Cardiovascular (fase crônica). Departamento de Ergometria e Reabilitação Cardiovascular da Sociedade Brasileira de Cardiologia. Arq Bras Cardiol 1997; 69:267-291.

11. Williams MA, Ades PA, Hamm LF, Keteyian, La Fontaine TP, Roitman JL, et al. Clinical evidence for health benefit from cardiac rehabilitation: An update. Am Heart J 2006; 152:835-841.

12. Costa RVC, Carreira MAMQ. Ergometry: ergospirometry, scintillography and stress echocardiography. São Paulo: Atheneu; 2007.

13. Consenso Brasileiro em Doença de Chagas. Health Surveillance Secretariat of the Ministry of Health. Rev Soc Bras Med Trop 2005; 38 (supl III):7-29.

14. Dias JCP, Coura J. Clínica e Terapêutica da Doença de Chagas: uma abordagem prática para o clínico geral. Epidemiologia. Rio de Janeiro: Ed. Fundação Oswaldo Cruz; 1997.

15. Koberle F. Cardiopathia parasympathicopriva. Munch Med Wochenschr 1959; 101:1308-1310.
16. Curtis BM, O'Keefe Jr JH. Autonomic tone as a cardiovascular risk factor: the dangers of chronic fight or flight. Mayo Clin Proc 2002; 77:45-54.

17. Guariento ME, Orosz JEB, Gontijo JAR. Clinical Interaction between Chagas disease and Primary Arterial Hypertension in an Outpatient Service. Arq Bras Cardiol 1998; 70:431-434

18. Guariento ME, Ramos MC, Gontijo JAR, Carvalhal SS. Chagas disease and primary arterial hypertension. Arq Bras Cardiol 1993; 60:71-75.

19. Bertanha L, Guariento ME, Magna LA, Almeida EA. Clinical-laboratory characterization of hypertensive Chagas patients without manifestation of heart failure. Rev Soc Bras Med Trop 2008; 41(supl III):163-168.

20. Ianni BM, Mady C, Arteaga E, Fernandes F. Cardiovascular Illnesses Observed whilst following of a Group of Patients with the Indeterminate Form of Chagas Disease. Arq Bras Cardiol 1998; 71:21-24.

21. Bestetti RB. Disfunção autonômica na Cardiopatia Chagásica Crônica: fator importante na patogênese e na historia natural da moléstia. Rio de Janeiro: Ed. Fundação Oswaldo Cruz; 1997.

22. Palmero HA, Caeiro TF, losa DJ. Distinctive abnormal responses to tilting test in chronic Chagas' disease. Klin Wochenscbr 1980; 58:1307-1311.

23. Palmero HA, Caiero TF, losa DJ. Effect of Chagas' disease on arterial blood pressure. Am Heart J 1979; 97:38-42.

24. Rozanski A, Blumenthal JA, Davidson KW, Saab PG, Kubzansky L. The epidemiology, pathophysiology, and management of psychosocial risk factors in cardiac practices: the emerging field of behavioral cardiology. J Am Coll Cardiol 2005; 45:637-651.

25. Roveda F, Middlekauff HR, Rondon MU, Reis SF, Souza M, Nastari L, et al. The effects of exercise training on sympathetic neural activation in advanced heart failure. J Am Coll Cardiol 2003; 42:854-860.

26. Negrão EC, Rondon MUPB. Physical exercise, hypertension and baroreflex control of blood pressure. Rev Bras Hipertens 2001; 8:89-95.

27. Sociedade Brasileira de Cardiologia. Diretrizes de Reabilitação Cardíaca. Arq Bras Cardiol 2005; 84:431-440.

28. Lima MMO, Rocha MOC, Nunes MCP, Sousa L, Costa HS, Alencar MCN, et al. A randomized trail of the effects of exercise training in Chagas cardiomyopathy. Euro J Heart Fail 2010; 12:866-873. 